\title{
Virtue and Proper Use in Plato's Euthydemus and Stoicism
}

DOI: $10.14746 / p e a .2019 .1 .2$

\section{DIMITRIOS DENTSORAS / University of Manitoba /}

\section{The argument from use}

In their attempt to show that external and bodily advantages such as health, wealth, and fame are not good but indifferent with regard to happiness, the Stoics employed the following argument (henceforth the "argument from use"):

- The things that can be used both well and badly are neither good nor bad, but rather indifferent.

- External and bodily advantages, such as health, strength, and money, can be used both well and badly.

Therefore, such advantages are not good, but indifferent. ${ }^{1}$

\footnotetext{
${ }^{1}$ Various versions of this argument appear in D.L. 7.102; S.E. M. 11.61; P. 3.177; Plu. Stoic. Rep. 1048 C.
} 
Our sources do not make any reference to the argument's provenance, but its resemblance to arguments in Euthd. $280 \mathrm{oc}-81 \mathrm{~d}$ and Men. $87 \mathrm{c}-88 \mathrm{~d}$ indicates a Platonic origin. ${ }^{2}$ The argument's place in our sources, in the middle of some of the most extensive orthodox expositions of the Stoic notion of indifference, could lead one to think that the Stoics thought of it as the central argument in favor of the indifference of external and bodily advantages. But, its presentation in our sources is brief and without any elaboration or justification for its premises. More alarmingly, when stark Stoic opponents Sextus Empiricus and Plutarch present the argument, they offer no response, apparently deeming it too unimportant to warrant one.

One can only conjecture on the cause of this apparent neglect. A possible reason may have to do with the argument's fate when Socrates presents it in the Platonic works, especially the Euthydemus. There, Socrates employs the argument from use, by drawing a parallel between wisdom and crafts such as carpentry, in order to show that possessions such as health and wealth are neither good nor bad by themselves. But, he falls short of providing a conclusive account of the nature of happiness and of the way in which wisdom leads to it. Socrates' incomplete account leaves possessions with an important role to play as a necessary requirement for the acquisition of happiness.

Socrates' failure to provide a definitive account indicates that the Platonic argument from use and the craft analogy that gives rise to it are inadequate for defending the strong Stoic claims about the indifference of possessions and about virtue's sufficiency for happiness. I argue that the Stoics retained the argument from use and the craft analogy associated with it, but for different purposes than usually thought. Moreover, the Stoics made significant adjustments to the Socratic analogy between virtue and other kinds of expertise, which reveal their novel understanding of happiness as a rational perfection that leads to agreement with nature. Their aim, in doing so, was to provide the strongest defense for virtue's sufficiency for happiness.

The following section discusses Socrates' use of the craft analogy in Plato's Euthydemus. I outline Socrates' difficulties in employing the craft analogy to support virtue's necessity and sufficiency for happiness, and I present some recent attempts to resolve these difficulties. I then move to the Stoics' treatment of the craft analogy and their version of the argument from use. After some remarks on the relationship of the Stoic moral views to Plato's Socrates, in Section Three, I discuss the major differences between the Stoic argument from use and the Euthydemus, in Section Four. Section Five discusses the Stoics' understanding of the relationship between virtue and the other crafts. Finally, Section Six presents some of the most original features of the Stoic argument from use and discusses how it fares in supporting virtue's sufficiency for happiness.

\footnotetext{
2 See, for example, Long and Sedley (1987: 350), who present the Stoic argument as "largely a Stoicized version of Plato."
} 


\section{Goodness and indifference in the Euthydemus}

The soundness of the argument from use obviously depends on how one is to understand the first premise that things that can be used both well and badly are neither good nor bad, but indifferent. At first sight, a thing's goodness and the way in which it is used seem to be two unrelated attributes. ${ }^{3}$ Undoubtedly, money, strength, and other such advantages can be put into bad use and make someone miserable, as countless examples of gluttons, thugs, and tyrants show. But this does not mean that money or strength themselves are not good. Why not simply say that tyrants and thugs put to bad use things that are generally good and suffer as a result?

A response to this challenge appears in Plato's Euthydemus, where Socrates presents an argument in favor of the view that possessions such as money, health, and fame are not good in themselves, but require wisdom to provide one with any benefit (Euthd. 28 oc-281d). ${ }^{4}$ Socrates' starting point in the argument is the uncontroversial claim that goodness should be understood as being useful and beneficial by making a contribution to happiness. According to common opinion, which provides the starting point for Socrates' argument, happiness, or "doing well," consists, at least primarily, in the possession of conventional goods, i.e., it consists in being healthy, rich, famous, etc. ${ }^{5}$ This is the most obvious understanding of the claim that happiness is something that we acquire through having many good things, such as health, money, moral qualities, and wisdom (Euthd. 279 b, repeated at 28oc). ${ }^{6}$ But, at Euthd. $280 \mathrm{oc}$, Socrates makes a distinction between all the aforementioned goods and the benefit they bring about. The distinction is followed by the claim that the ability to bring about some benefit cannot be assigned to the mere

3 This objection was brought forth by the Peripatetics, who rejected the argument from use. On Alexander of Aphrodisias' Peripatetic response to the argument, see Sharples (2000).

4 Socrates' argument is part of his first attempt to convince young Clinias to purse wisdom and virtue (Euthd. 278d-282d, with a second attempt appearing at Euthd. 288d-292e). Socrates' hortatory exhibition is a response to Euthydemus' and Dionysodorous' half-serious eristic arguments, which seem to confuse, rather than enlighten Clinias. While Socrates does believe that there is something to be learned by the eristic couple's method, he advises Clinias to be wary of lapsing into a mere word-play, and encourages him to focus on the moral lessons that can be learned by philosophical reflection. For the place of Socrates' hortatory speeches within the framework of the Euthydemus and the contrast between eristic and Socratic dialectic, see Chance (1992: 54) and Erler (2017: 93).

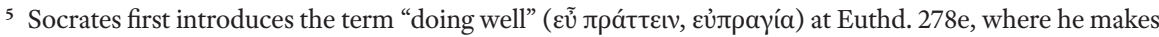
the apparently obvious remark that "all people wish to do well." At Euthd. 280b, Socrates uses the term "being

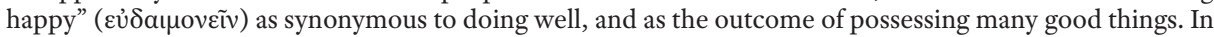
the two cases, Socrates merely refers to the popular conception of well-being as a quality that characterises the whole of one's life (rather than a feeling of elation and self-satisfaction that most think as happiness today). The term is intentionally broad and contains all the qualities that one would associate with a life that is going well, a life that one would be proud for, and that is free from disappointments, regrets, and failures. In this sense, the popular conception of happiness that Socrates refers to in the Euthydemus is similar to the Stoic description of happiness as "good flow of life" (cúpoıı ßíou) (see Stob. 2.77, S.E. M. 11.30).

${ }^{6}$ In Euthd. 278e and Euthd. 280b, Socrates merely states that we are happy if we possess many good things. In Euthd. 280c, on the other hand, he makes the claim that we become happy through ( $\delta$ ià) good things. In

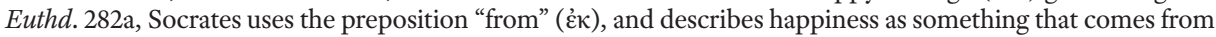
the use of possessions. 
possession of money, health, and the like. Drawing a parallel with crafts, such as carpentry, Socrates claims that all possessions need to be used in order to provide any benefit, just as wood and tools need to be used by a carpenter in order to produce a table. Moreover, these possessions need to be used well. If one were to use these possessions wrongly, one would get harm rather than benefit from them (Euthd. 281a).

According to Socrates, external, bodily, and even psychic presumed goods do not affect the quality of their use. For this reason, they can be harmful and bad as much as they can be useful and good. The only exception is wisdom, which can never be used badly, because it consists in the knowledge of how to use one's possessions in a way that produces benefit and happiness. Wisdom, therefore, is the only thing that is always beneficial and good. ' At Euthd. 281d, Socrates sums up the argument:

With respect to all the things we called good in the beginning [wealth, fame, strength, etc.], the correct account is not that in themselves they are good by nature, but rather as follows: if ignorance controls them, they are greater evils than their opposites, to the extent that they are more capable of complying with a bad master; but if good sense and wisdom are in control, they are greater goods. In themselves, however, neither sort is of any value. ${ }^{8}$

Socrates does not give any description of the benefit that we get from the wise use of possessions, leaving us with no definite idea about what happiness consists in. He also does not say much about the goodness of possessions. If possessions are not good in themselves, in what way are they good?

One possible answer, proposed by Terry Irwin, is based on the analogy between wisdom and crafts such as carpentry, which Socrates alludes to at Euthd. 281a, and assigns an instrumental value to possessions (Irwin 1995: 68-77). In the case of crafts, tools and supplies are instrumentally good in producing some final product (e.g., a house) by being expertly used. In the case of wisdom, possessions are used to provide a life that can be considered happy (for example, a life where one's desires are satisfied, that is free from regrets and disappointments, that one can be proud of, etc.). But, according to the instrumentalist account, wisdom should not be good by itself, either, since it also plays an instrumental role in bringing about the self-satisfied and carefree life. Moreover, as Irwin notes, wisdom requires possessions, in order to be beneficial and good, just as a carpenter requires tools and wood in order to build a house. In that case, wisdom is no different from possessions, since both are necessary but not sufficient for happiness.

\footnotetext{
7 Although Socrates only mentions wisdom, rather than virtue in general, in this passage of the Euthydemus, he clearly seems to conceive of the whole of virtue as some sort of knowledge, which he contrasts with the often praised character traits such as a settled disposition to defy death in a battle or to obey the law, which most people (mistakenly) consider to be justice and bravery (Euthd.279b-279c). Wisdom and (true) virtue, therefore, should be considered as essentially the same. On this point, see Dimas (2002: 2).
}

8 Translations from the Euthydemus follow Kent Sprague (1965). 
But this seems to contradict the claim Socrates repeatedly makes in the Euthydemus and elsewhere (Irwin 1995: 73). ${ }^{9}$

Gregory Vlastos offers a competing account by introducing an additive conception of happiness, according to which external goods and virtue possess two different kinds of goodness, both of which make an independent contribution to happiness (Vlastos 1991: 214-231). ${ }^{10}$ While both are good, the extent to which virtue and external goods contribute to happiness is vastly different. Although possessions have an additive affect and contribution to happiness, they are minimal goods and their contribution is too small to reach the happiness threshold all by itself. So, without virtue, all the money and power in the world are worthless, since they cannot bring happiness, and happiness is all that matters. On the other hand, virtue by itself possesses enough value to make one happy and is, in this sense, good in itself.

Vlastos' account aims at providing an argument in favor of virtue's sufficiency for happiness. But it flies in the face of the craft analogy and Socrates' claim that possessions have no value by themselves, but only become valuable when used by wisdom. It also leaves aside the most intriguing of Socrates' claims, namely the fact that possessions, such as health and wealth, can be greater or lesser goods than their opposites, such as disease and poverty, depending on their use (Euthd. $281 \mathrm{~d}$ ). ${ }^{11}$ The view that virtue can turn external and bodily possessions into goods is reminiscent of $A p$. 3ob, where Socrates claims that people should care about virtue rather than amassing wealth because "wealth does not bring about virtue, but virtue makes wealth and everything else good for men, both individually and collectively." ${ }^{12}$ As Burnyeat 2003 maintains, it would be odd for Socrates to advocate that virtue makes people rich. Rather, Socrates, in the Apology, seems to think that virtue can turn the possessions one has into things that are good and beneficial, i.e., to things that are part of one's happiness, and that possessions do not make any independent contribution to happiness. Vlastos' account seems incompatible with this aspect of virtue, since it assigns an independent inherent goodness to possessions, while it presents wisdom as being concerned with a completely different realm (that of morality), rather than with making possessions beneficial.

A different interpretation is offered by Christopher Bobonich, who presents possessions as dependent goods that offer no benefit (and are, thus, not good) unless they are

9 The claim that virtue is sufficient for happiness appears, among other places, in Euthd. 280a; Ap. 30c; Grg. 470e, 507b. For the attribution of the sufficiency claim to Socrates, see also Cic. Fin. 5.84.

${ }_{10}$ Vlastos identifies two kinds of goods, moral and non-moral. Moral goods are supplied by wisdom alone. Non-moral goods, on the other hand, can come from a variety of sources (luck, wisdom, other skills, etc.).

11 This seems to be the most challenging view presented by Socrates in the protreptic, and stands in contrast with the position adopted by Clinias at the beginning of the discussion (Euthd.279a-279b), according to which things such as health, beauty, and honour are always good without qualification, and their opposites bad. Clinias' reserved response to Socrates at Euthd.281e reflects his unease: "it seems (paívetau) to be as you [Socrates] say."

12 For a discussion of this Apology passage, see Burnyeat (2003). Vlastos (1991: 220) also mentions the passage, but does not attach any importance to it, taking it as a mere repetition of a previous point $(A p .29 \mathrm{e})$ that presented money as inferior to virtue (but, presumably, still good, for Vlastos). 
accompanied by wisdom and virtue (Bobonich 2002: 136). According to Bobonich, only wisdom is an independent good, and, thus, good-in-itself, since it requires nothing further in order to benefit. Wisdom - and the moral goodness that accompanies it - are constitutive parts of happiness, and need no external possessions in order to come about. Other possessions depend on wisdom, not necessarily for coming about (one can get them by luck), but for conferring any benefit, i.e., for becoming parts of happiness. Without wisdom and moral virtue, one's life is inevitably misdirected and ultimately unsatisfying, since it fails to recognize what is truly good and directs people to the kinds of pursuits that Socrates criticizes in the Apology. Hence, it is necessary to have wisdom in order to gain any benefit from possessions.

Bobonich's presentation of wisdom as an independent good avoids the problem faced by Irwin's instrumentalist model, and allows virtue to be good just-by-itself. But this comes at the expense of the analogy between wisdom and the crafts, and of the idea that the wise use of externals is supposed to turn them into goods. It also leaves unanswered the question regarding the product that wisdom, conceived as a sort of craft, is supposed to bring about. Prima facie, it seems that the only product of wisdom is knowledge (and the moral goodness that comes with it). But, if that is the case, then possessions have no effect on it. Neither do possessions seem to change when they are accompanied by knowledge of the good. This knowledge, rather, seems to be an add-on. In this case, it is hard to see how the fact that wisdom is an independent good can explain why other possessions are dependent goods. ${ }^{13}$

A more radical interpretation of Euthd. 281d is adopted by Panos Dimas and Julia Annas, who reject the attribution of any goodness (instrumental, minimal, or dependent) to external possessions (Annas 1999: 42-44; Dimas 2002). The interpretation is based on Socrates' summary of the argument at Euthd. 281e, which proclaims that possessions are neither good nor bad, without adding the qualification "by themselves," and on the discussion of wisdom's product in the second exchange between Clinias and Socrates, at Euthd. 288d-292e. In the second passage, Socrates stumbles on a persistent difference between wisdom and other kinds of expert knowledge. In the case of other crafts, their product is not beneficial and good in itself, but rather something that could be beneficial when used properly by some further craft or expertise. For example, the products from the exercise of the blacksmith's craft (e.g. horseshoes) are, in turn, used by other experts (horsemen), who determine the desirable qualities of the product. On the other hand, since wisdom is unconditionally good, its product must be unconditionally good, i.e., it must be good without a requirement for further use (Euthd. 292a). But the only thing that satisfies this is wisdom itself. Thus, the product of wisdom's function must be none other than wisdom itself (Euthd. 292d).

Socrates finds this answer circular and unacceptable, so he ends his inquiry with an aporia. But, Dimas and Annas think that the aporia opens the door for a conception of

13 Bobonich (2002: 146) considers this fact to be a condition for his Dependency Thesis. 
happiness (the product from wisdom's exercise) as consisting purely in wisdom's exercise. In this case, possessions function as "facilitators" that allow the performance of wise and virtuous acts, such as fighting bravely in battle, in the case of strength, or helping the poor, in the case of wealth. ${ }^{14}$ The more such possessions the wise person has, the more she is able to do, and the happier she can be, as a result. But possessions are indifferent, since they never become constitutive parts of happiness. Even when conjoined with wisdom, i.e., when they are used wisely, possessions do not add anything to happiness on their own right. The only quality possessions have is the ability to amplify the range of a person's activities.

The Socratic idea that possessions function as facilitators for the exercise of wisdom, rather than contributors to happiness, provides a strong motivation for Socrates' claim that we should pursue wisdom above everything else. Without wisdom, no amount of possessions can ever have any benefit. But, Socrates remains unclear when it comes to the question of whether some possessions are needed at all in order to become happy, or whether wisdom alone is enough for this. If external and bodily advantages can increase the happiness of the virtuous person, as Socrates admits, then their opposites must decrease her happiness. This inevitably leads to a question regarding the amount of the virtuous person's happiness that the presence of external and bodily hardships can take away. Is it possible that, in cases of extreme deprivation of external and bodily advantages, the virtuous person is actually not happy at all? Socrates does not address the question in the Euthydemus. ${ }^{15}$ But it is hard to see how the sufficiency thesis can be maintained, if performing virtuous actions, such as fighting bravely in battle or helping the poor, requires at least a minimum of (appropriate) possessions, such as strength and money. Without them, wise activity and, consequently, happiness seem impossible. ${ }^{16}$

\section{The Stoics and Plato's Socrates}

Despite his apparent success in convincing young Clinias that wisdom is "the only thing which makes man happy and successful" (Euthd. 282c), Socrates falls short of providing a conclusive account of the craft-like knowledge that constitutes wisdom and of how wisdom manages to lead to happiness through the use of one's possessions. Socrates is clear that the effect possessions may have on one's happiness is dependent upon the

${ }_{14}$ The description of possessions as “facilitators” of wisdom's exercise appears in Dimas. Annas (1999: 42) also talks about possessions facilitating the exercise of virtue.

15 The absence of any answer to this question is noted by Parry (2003).

16 The shortcomings of Socrates' account in providing a definitive defence of virtue's sufficiency for happiness are discussed by, among others, Rider (2012) and Jones (2013). Both Rider and Jones claim that Socrates neither manages nor intends to argue for wisdom's sufficiency for happiness. Instead, his goal is to merely encourage Clinias to pursue virtue above everything else, by showing how it is necessary for happiness. For the broader view that Socrates did not completely endorse the necessity and sufficiency thesis, see also Reshotko (2006: 95-117) and Brickhouse and Smith (1994: 103-136). 
existence of wisdom. But, the craft analogy makes it impossible to think of possessions as completely indifferent with respect to happiness, even if their role is never fully determined. Without any definitive answer to Socrates' inquiry, a lot is left unanswered in the Euthydemus, as demonstrated by the number of competing interpretations.

Of course, this should not come as a surprise; after all, the moral views of the historical Socrates, as well as those of Socrates' Platonic persona, are notoriously elusive, and have been regarded as such since antiquity. It is not uncommon, for example, among Hellenistic philosophers to read Plato's Socrates from their own philosophical perspective, pointing at various parts of Plato's works that fit their philosophical position, and interpreting the rest of the dialogue in question from that particular standpoint. The skeptical turn of the Academy under Arcesilaus and Carneades, and the syncretism of the late Academic Antiochus of Ascalon are two of the many examples of such revisionist readings of Plato's Socrates. Arguably, the same could be said about the Stoics, who evidently saw themselves as belonging to the Socratic moral tradition. ${ }^{17}$ But, being called Socratics, a title that the Stoics shared with philosophers holding very different views, is too broad for determining the Stoics' position on the specific ideas Socrates adopts in Plato or elsewhere. Can anything be said about the Stoics' views on the arguments Socrates uses in presenting the relationship between wisdom and possessions (especially the argument from use and the related analogy between wisdom and the crafts) in the Euthydemus?

Julia Annas makes a strong case for the convergence between the Socratic and Stoic views on the relationship between virtue, possessions, and happiness. According to Annas, Socrates' position in the Euthydemus should be interpreted in Stoic terms, as subscribing to the idea that moral value is the only good and that virtue is sufficient for happiness. Moreover, Annas claims that Hellenistic philosophers, both Stoics and Platonists, recognized that Socrates essentially held the Stoic moral position (Annas 1999: 48). In support of this bold claim, Annas adduces a passage from Alcinous' Handbook of Platonism, which uses some ostensibly Stoic vocabulary when presenting possessions as the "matter" of virtue, and refers to the Euthydemus when presenting the idea that only things that participate in knowledge (of the first principle) are good. She also mentions the anecdotal report that the middle Stoic Antipater wrote in favor of the view that Plato's ethics were in agreement with the Stoics ${ }^{3}{ }^{18}$ It is no coincidence, for Annas, that Antipater is also associated with the description of virtue as a stochastic craft similar to medicine, whose goal consists in exercising the craft in the best possible way, while its target is some external good (health in the case of medicine, natural advantages such as life and strength in the case of virtue). According to Annas, Antipater saw himself following Socrates in

17 For the Stoics' self-declared connection to Socrates, see Long (1988: 161), Striker (1996), Irwin (1998: 155), Frede (1999: 71), and Schofield (2003: 234). For a lengthy and detailed account of the historical aspects of the relationship between the Stoics and Socrates, see Alesse (2000).

${ }_{18}$ Alcin. Didaskalikos 27.2; 27.4. For Antipater's claim that Plato supported virtue's sufficiency for happiness, see Dillon (1993: 169), who, nevertheless, notes that we do not know how Antipater argued for this position. 
adopting the craft model of virtue in order to demonstrate how and why virtue is the only good and sufficient for happiness.

I believe that Annas' view makes too much out of our rather scant evidence, and is somewhat misleading with respect to both Plato's Socrates and the Stoics' reception of the craft analogy and the argument from use. ${ }^{19}$ With respect to Plato's Socrates, despite the repeated claim that possessions lack any goodness in themselves, Socrates stops short of denying them any goodness whatsoever. A major obstacle to such a denial is the craft model that Socrates repeatedly employs. Moreover, despite Socrates' insistence on the importance of knowledge and the (relative) unimportance of possessions, he falls short of arguing conclusively in favor of a conception of happiness that consists in knowledge alone. This is, at least, the case in the Euthydemus, where Socrates reaches an aporia when he discovers that the product of wisdom must be none other than a kind of knowledge of the good (Euthd. 292d).

Although it is impossible to determine how much the Stoics engaged in an analysis and criticism of specific Platonic dialogues, one could imagine that they had in mind Socratic arguments similar to those that appear in the Euthydemus, when presenting their own argument from use and when referring to virtue as a craft. ${ }^{20}$ Yet, there is little reason to believe that the Stoics thought Socrates had their elaborate conception of happiness in mind, when he discussed the value of wisdom with his contemporaries, or that they saw themselves as trying to reinterpret the Platonic dialogues in ways that made them compatible with Stoic ethics. It is probably better to think that the Stoics saw themselves as defending Socrates' moral position only in the broadest sense. The Stoics were in agreement with the two main moral views attributed to Socrates: virtue is some sort of knowledge and virtue is necessary and sufficient for happiness. They were also attracted to the idea of virtue as a craft that unfailingly makes one happy. With this broad agreement in mind, they developed an idea of virtue as craft that formed the base for the argument from use and pointed to the indifference of possessions. But, the Stoics also seem to be quite aware of the limitations of the craft model in defending virtue's sufficiency for happiness, some of which Socrates faces in the Euthydemus. ${ }^{21}$ In fact, some of their descriptions of virtue as a craft, which the following sections discuss, lead to a conception of happiness based on knowledge of and agreement with nature that goes beyond anything we find in Plato's Socrates.

${ }^{19}$ It is hard to see how one could make much out of the Alcinous passage that Annas cites. Despite the occasional use of Stoic vocabulary, which would probably go unnoticed for anyone writing in the first century BCE, there is no explicit reference to Stoicism, or any attempt to equate the Platonic and the Stoic moral positions.

${ }^{20}$ Diogenes Laertius and Plutarch tell us that Zeno and Chrysippus wrote works entitled Republic that specifically targeted Plato's masterwork. It is likely that they engaged in similar criticism of other dialogues, but it is impossible to go far beyond speculation, due to the scarcity of our sources.

${ }^{21}$ Annas (1993: 65) also seems to make a similar point, by calling Socrates' argument in the Euthydemus a "quarry" rather than a "model" for Hellenistic philosophers, which demonstrates some of the apparent difficulties faced by Socrates' central moral theses. At the same time, Annas considers Socrates' moral position in the Euthydemus to be a "clear forerunner" of the Stoics (a point that, I think, should be significantly qualified). 


\section{The Stoics on proper use and happiness}

The most evident difference between the Stoic views on goodness and the moral position Socrates appears to adopt in Plato has to do with the indifference of possessions, such as health and money, vis-à-vis happiness. The general Stoic description of "indifferents" as things that are neither good nor bad, or as things between good and bad (D.L. 7.102; Stob. 2.79) allows one to think that Stoic indifference corresponds to Socrates' description in the Euthydemus, insofar as external and bodily advantages are things that affect the amount of happiness the virtuous enjoy, although they are not constitutive parts of happiness. But a closer look at the Stoic notion of indifference reveals a radically different picture.

One place where such a radical difference becomes apparent is Diogenes Laertius' discussion of the value that indifferents possess. In his report of Stoic orthodoxy, Diogenes distinguishes two kinds of value. One belongs only to the good, i.e., virtue, and is defined as "a contribution to a life in agreement," which the Stoics identified with happiness. The other one belongs to preferable indifferents such as health and wealth and is defined as "a use contributing to a life in accordance with nature" (D.L. 7.105). ${ }^{22}$ According to the Stoics, a healthy life is more natural than, and preferable to, a life accompanied by disease in the sense that it is in accordance with what nature has generally determined as the proper way for any living organism to live and function. One way in which health is more natural is by allowing a range of activities that would not be possible without it, such as reproduction, active participation in the military defense of a city, etc. But even if health were not to make such a practical difference, the Stoics believed that health is in accordance with nature on its own right. ${ }^{23}$ Moreover, indifferents contribute to the naturalness of life in the case of both the virtuous and the non-virtuous, and for the same reasons, because they allow a certain range of activities and carry nature's quality mark as being the way things should be.

On the other hand, the Stoics maintained that the indifferents, which vary in quantity and duration, offer no contribution or assistance at all to happiness, either constitutively or by facilitating certain kinds of actions. ${ }^{24}$ Thus, it is not merely the case, as Socrates suggests in the Euthydemus, that external advantages are not good by themselves, but can facilitate happiness when used by wisdom. Rather, according to the Stoics, advantages such as health and wealth never make any contribution to happiness, even when they are

${ }^{22}$ For a similar view attributed to the Stoics, see also Alex.Aphr. de An. 167.18 and S.E. M. 11.59.

${ }^{23}$ Cf. the view attributed to the heterodox Stoic Aristo of Chios by Sextus Empiricus in M. 11.64-67. There, Aristo employs the argument from use in order to show that health is not only indifferent, but also non-preferable, since one would rather be sick than healthy, if one had to serve a tyrant. But, Aristo seems to misrepresent Zeno's position, by assuming that the orthodox Stoic claim that health is naturally (and generally) preferable amounts to the claim that health is preferable under all circumstances, which is something no Stoic would accept.

${ }^{24}$ On this, see D.L. 7.104; Stob. 2.79; S.E. M. 11.59. 
properly used. ${ }^{25}$ At the heart of this claim lies a significant difference regarding the nature of happiness. According to the Stoics, happiness does not consist in performing certain kinds of actions (e.g., helping the poor, defending one's country, obeying the law, doing philosophy, etc.), as Socrates seems to suggest in the Euthydemus. Rather, the Stoics identified happiness with the way in which one uses these indifferents, i.e., with the thoughts regarding what is truly good and what is merely appropriate that one has when helping the poor, fighting battles, or doing philosophy. This is the thought that D.L. 7.104 expresses when he reports that, for the Stoics, "it is possible to be happy even without them [the

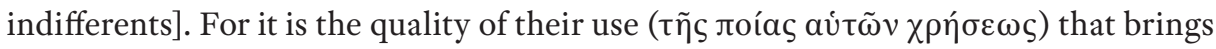
happiness or unhappiness." In accordance with this idea, the Stoics maintained that it is possible for the non-virtuous to perform the same actions as the virtuous (obeying the law, helping the poor, etc.), while never acting rightly and, as a result, never reaching happiness. Chrysippus expresses this idea in his account of the moral progress towards virtue: "The man who has progressed to the furthest point [towards virtue] performs all appropriate acts without exceptions and omits none. Yet his life is not happy."

The Stoic emphasis on one's thoughts and motives (rather than physical actions) in determining moral worth and happiness was important for the view that virtue is sufficient for happiness in the Stoics' debate with the Peripatetics and the Academic Skeptics, primarily Carneades. The Stoics agreed with their opponents that the actions which the virtuous person is able to perform are determined, to a significant extent, by the amount of available external and bodily advantages, which often lies outside the wise person's control. The Stoics also accepted that, if happiness depended on being able to perform certain kinds of actions, an extreme deprivation of possessions would render even the virtuous unhappy. However, the Stoics replied that happiness does not depend on what one does, but on the manner of one's actions. Virtue includes all the thoughts that constitute the appropriate and beneficial way of acting. ${ }^{27}$ The mere presence of virtue in one's soul, therefore, according to the Stoics, necessarily and always brings about the right disposition and, consequently, happiness.

\section{Virtue and the other crafts}

By shifting their focus from the actual practice of actions, such as helping the poor and fighting for one's country, to the manner in which these actions are performed, the Stoics were able to show why external and bodily possessions do not facilitate happiness

\footnotetext{
${ }^{25}$ For this point, see Brennan (2005: 120), who argues, I think correctly, against Long and Sedley (1987: $358)$.

${ }^{26}$ Stob. 5.906 (SVF 3.510). For a similar view, see Cic. Fin. 3.20-21 (SVF 3.522).

${ }^{27}$ For the Stoic definition of virtue as the knowledge of how to act properly, see Stob. 2.59 and Alex.Aphr. de An. 167.4 (SVF 3.204).
} 
and, consequently, why virtue could be thought of as sufficient for happiness. But this seems to come at the cost of abandoning the craft analogy. It also renders the argument from use rather superfluous, since it is not the fact that possessions can be used well or badly that explains their indifference - after all, they remain indifferent even when used rightly.

With this in mind, how should we understand the analogy between wisdom and the crafts, which apparently provides the basis for the argument from use and the indifference claim? In the case of all other crafts, the tools and materials available to the craftsman may be less significant than his skill, but they are not indifferent with respect to the quality of the final product of the craft's exercise. On the other hand, as the Stoics proclaimed, the materials that wisdom uses to make one happy have no effect on wisdom's products. Wisdom, therefore, cannot be like other crafts.

As our sources indicate, the Stoics made a considerable effort to maintain the parallel between wisdom and the crafts at the face of increasingly evident dissimilarities. The issue of finding a proper description of wisdom as a craft became prominent in Hellenistic philosophy in the context of an attack launched by the Academic skeptic Carneades against the Stoic notion of indifference. According to Carneades, the Stoic wise person's pursuit of health, freedom, and other preferable indifferents shows that such possessions are goods, contrary to what the Stoics maintained. For why else would the sage do "all in his power, continually and unerringly, in order to achieve the things that are naturally preferable," as the Stoics proclaimed ${ }^{28}$ The orthodox Stoic reply to Carneades, presented by the Stoic Antipater of Tarsus, consisted in the presentation of virtue as a stochastic craft analogous to medicine and navigation, whose goal consists in the proper performance of the relevant skill, and whose success is independent of the outcome that its practice may have (such as crossing an ocean or healing a patient). ${ }^{29}$ Contrary to such productive crafts as house-building, Antipater maintained, the wise doctor and captain are not evaluated with respect to some object external to their craft (a house, in the case of the builder), whose quality, or even existence, may lie outside the craftsman's control. Rather, wise doctors and captains are valued based on the skill and knowledge they demonstrate in exercising their craft, even when they fail to meet their external goal of healing and offering safe transit. Similarly, although the virtuous person might fail in attaining what she has set up as her target (the acquisition of such preferable indifferents as health or freedom), she never fails in attaining her goal, which consists in the exercise of her virtue and nothing else..$^{30}$

\footnotetext{
${ }^{28}$ This is the formulation of the telos attributed to Antipater by Stob. 2.76.

${ }^{29}$ In our ancient sources, the debate is mentioned by Cicero in the fifth book of his De finibus. Antipater's position regarding the end is criticized by Plu. Comm. not. 1070F and by Alex.Aphr. de An. 159.33 (SVF 3.66). On the Stoic notion of stochastic crafts and the related debate, see Striker (1986), Long (1967), and Inwood (1985).

${ }^{30}$ For the distinction between goal and target in Stoicism, see Cicero's archer analogy in Fin. 3.22, discussed by Inwood (1985).
} 
Antipater's stochastic craft seems revealing with regard to how we evaluate certain experts: a doctor who fails in treating an incurable cancer patient after having prolonged his life beyond all expectation may be considered better than a doctor who manages to cure a simple cold by prescribing a generic drug without examining the symptoms in detail. But, as Striker 1986 points out, the analogy no longer applies when one considers the goals that doctors and captains have, and the value they attach to these goals. Doctors value health as a good whose worth is independent from the proper exercise of their craft. When they fail to cure a hopelessly ill patient, doctors may say that they did all they could, given the circumstances, and feel that they accomplished their medical duty. Yet, they also feel that they have failed in their goal (even though through no fault of theirs) and that this failure is regretful. Surely, the health of their patient is no matter of indifference to them. If the Stoic wise person considers all the advantages that she pursues to be indifferent to her happiness, then she is not like a doctor trying to cure his patient.

So, why would the Stoics insist on the craft analogy at all, and even try to draw a parallel between virtue and such specific crafts as medicine and navigation? The best answer, I think, is that the Stoics did not intend to go beyond the general claim that virtue is an expertise that leads to happiness, and that Antipater's use of the stochastic crafts is only employed for a very specific purpose, namely to show that the virtuous person's wisdom is not a theoretical knowledge, but it involves a lot of beliefs about indifferents, including knowing which indifferents should be pursued, how, and why. The objection Antipater faces from Carneades does not involve virtue's sufficiency for happiness, for the defense of which the craft analogy is a poor choice. ${ }^{31}$ Rather, the stochastic craft model provides the answer to how the virtuous person could care about indifferents, while thinking that failure to attain them is not something bad, since happiness consists solely in agreement with nature, i.e., it consists in having the right kinds of thoughts about what is good and what is (merely) preferable.

The central Stoic moral position, from Zeno to Antipater and beyond, is that happiness is achieved by bringing one's thought in harmony with nature's perfect rationality. This is something that virtue and only virtue can bring about. But, when fleshing out the kinds of thoughts the wise persons has, the Stoics maintained that a lot (actually, the majority) of these thoughts involve preferable, though indifferent things. ${ }^{32}$ This is the idea expressed by the Stoic claim that natural advantages provide the "matter" of virtue (Plu.

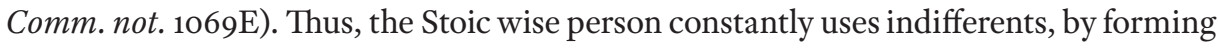
the right kinds of beliefs and impulses towards them, and by acting accordingly. But, the

31 Sharples (2004: 178), commenting on Alexander of Aphrodisias' argument against virtue's sufficiency for happiness in de An. 161.4 also suggests that "if the Stoics are to counter this argument, it must be by allowing a disanalogy between virtuosity in living and virtuosity in pipe-playing."

32 Brennan (2005) and Barney (2003) present a picture of virtuous deliberation and action that is based on the relative value of indifferents, rather than on considerations of morality. At the same time, Brennan notes that the "indifferents only" model of virtuous action is incomplete, and needs to make some space for cases where moral considerations trump considerations of benefit. I think Brennan and Barney offer a compelling picture of Stoic virtuous action that is consistent with my description of virtue's function. 
Stoic wise use of indifferents exhibits some obvious differences from the use of tools and materials other crafts engage in. These differences stem from the Stoic idea of happiness as agreement with nature and the doctrine that virtue is sufficient for happiness. The next section will discuss two of them.

\section{Virtue and its uses}

One of the unique features of virtue's craft, as the Stoics conceived it, has to do with the indifferents that virtue uses in order to bring benefit and, consequently, happiness. In his criticism of the Stoics' position concerning virtue and happiness, the Peripatetic Alexander of Aphrodisias mentions that crafts such as flute-playing require some appropriate or fitting instrument in order to be exercised (Alex.Aphr. de An.167). If virtue is like the crafts, it should also require health, money, and the other Stoic preferable indifferents (what Alexander refers to as "wishables" ( $\beta$ ou $\lambda \tau \tau \alpha$ )), whose proper use would provide happiness. But, in that case, possessing some appropriate external advantages, which may depend on chance, is necessary in order to use them correctly and gain any benefit. Therefore, virtue alone cannot be sufficient for happiness.

To this, the Stoics replied that, while all other crafts require some appropriate instruments, virtue can use all indifferents well, regardless of whether they are generally preferred or dispreferred. To support the claim that the wise person can use beneficially even disadvantages, such as disease and poverty, the Stoics could point to their account of acts such as suicide, which they endorsed under certain conditions. ${ }^{33}$ In the case of suicide, the virtuous person uses his death (which is generally something he tries to avoid) in order to secure a preferred indifferent, such as painlessness, or in order to avoid an immoral act, such as aiding a tyrant. Thus, under circumstances that call for a radical response, such as suicide, the virtuous person's appropriate indifferent is death, since painlessness and freedom from disgrace could not be obtained if the wise person were to remain alive and attempt to use his life rather than his death. ${ }^{34}$ Similar arguments could be made in cases where physical weakness steers someone from the vainglory life of politics to philosophy, or injury frees one from having to serve an unjust ruler.

At the same time, the external advantages that the virtuous person obtains through the use of generally dispreferred indifferents do not constitute any true benefit, according to the Stoics, since they do not make the virtuous person's life any happier. The true benefit from the wise and proper use of any indifferent lies exclusively in being in agreement with nature, i.e., it lies in following willingly what nature ordains, with the knowledge that whatever happens is part of a perfectly rational universal scheme for the proper and

\footnotetext{
${ }^{33}$ For a discussion of suicide as a case of using a generally dispreferred indifferent, see Dentsoras (2008).

${ }^{34}$ For the conditions under which the virtuous person will commit suicide, according to the Stoics, see D.L. 7.130; Stob. 2.110; Plu. Comm. not. 1060C (SVF 3.768). On the Stoic view of suicide, see Cooper (1999).
} 
best possible functioning of the whole of the cosmos. ${ }^{35}$ Nature's divine rational plan might require sometimes that the virtuous person fall sick or lose her fortune in a shipwreck. The Stoic wise person recognizes this and actively pursues even sickness and poverty, when she thinks that this is what nature requires of her ${ }^{36}$ In such a case, where agreement with nature is achieved by falling sick and by losing one's money, the virtuous person uses her generally dispreferred state of sickness and poverty in order to attain the benefit of being in harmony with nature and with nature's perfect plan of the cosmos.

According to this line of thought, happiness requires no particular indifferent in order to be attained. Rather, the existence of some indifferents is merely a necessary condition for virtuous action and happiness, in the way that heaven, earth, space and time are. ${ }^{37}$ As such, external benefits would not be causally related to the actions and happiness of the virtuous person. But, the Stoics also seem to have gone beyond presenting indifferents as mere necessary conditions for virtuous action and happiness. Their goal in doing so, apparently, was to defend virtue's sufficiency for happiness in extreme cases in which the virtuous person is prevented from performing any action by being chained to a wall or suffering a completely debilitating disease.$^{8}$ In such cases, the virtuous person seems to be worse off than being poor or painfully sick. In the latter cases, the virtuous is still able to exercise her virtue, by demonstrating fortitude and endurance, and is able to produce happiness as a result. But cases of forced inaction seem to make impossible the exercise of virtue and, consequently, the production of happiness. The Stoics could, of course, merely brush aside such cases as extremely rare exceptions to the general happiness of the virtuous life. But their description of virtue's function as proper use seems to address such extreme cases, in accordance with the Stoics' overall position that virtue's sufficiency for happiness can be most clearly demonstrated in cases of extreme hardship, such as torture and debilitating disease.

The Stoic reply to cases of forced inaction consisted in providing a description of the materials that virtue uses that is completely detached from any of the indifferents. The Stoics accomplished this by presenting virtue itself as what the virtuous person uses in order to yield benefit. ${ }^{39}$ The way in which virtue can use itself can be seen in the Stoics' theory of virtuous action. When faced with every decision and action, the virtuous person consults her experiences of life, which also constitute her knowledge and virtue,

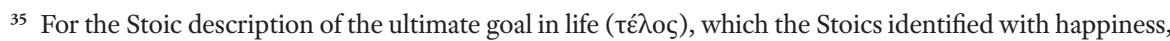
as being in agreement with nature, see D.L. 7.87; Stob. 2.75-76; Cic. Fin. 4.14.

36 See Epict. Diss. 2.6.9, quoting Chrysippus: "If I actually knew that I was fated now to be ill, I would even have an impulse to be ill. For my foot, too, if it had intelligence, would have an impulse to get muddy."

${ }^{37}$ For the attribution of this view to the Stoics, see Alex.Aphr. de An. 160.3 (SVF 3.64). For a discussion of indifferents as necessary conditions for the exercise of virtue, see Striker (1986).

38 See Alex.Aphr. de An. 161.17, who mentions that the virtuous will not be able to act at all if he falls in lethargy, dizziness, or frenzy.

39 The reference to using virtue, or using the virtues, appears in S.E. M. 11.61; Stob. 2.99; D.L. 7.128. 
and, based on them, determines what she should do and how. ${ }^{40}$ This involves assenting to propositions, some of which might be factual and some impulsive. These assents, according to the Stoics, constitute the action of the virtuous person. This is, in other words, all

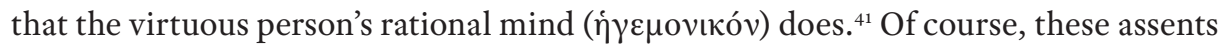
also translate into some external action, such as eating, spending money for charity, or killing oneself. But the benefit that the virtuous person gains from her action does not come from the external acts, which might involve the actual use of food, money, weapons, etc. Rather, it consists in the use of virtue itself, that is, in the use of virtuous thoughts and impulses, which bring forth new thoughts, impulses, and feelings..$^{42}$

The product that comes out of this use of virtue by the mind was identified by the Stoics with benefit and, consequently, with the good. According to our sources, the Stoics described benefit in a number of ways, identifying it with virtue, virtuous action,

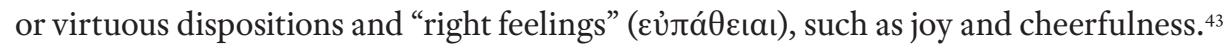
In virtually every description of benefit, the Stoics presented it as a state of the virtuous person's soul. As such, the good is independent of anything external, since the Stoic wise person is able to perform a virtuous action (i.e., have a virtuous impulsive thought), and enjoy the benefit and happiness that comes from it, regardless of the externals that are available to him. ${ }^{44}$ Although the particular action that the virtuous person performs may depend on the external circumstances he finds himself in (e.g., one cannot eat if there is no food around), his performance of virtuous actions in general is independent of any externals. In that sense, the virtuous person's eating when there is food around would be equally virtuous and good as his not eating when there is no food around. Hence, the virtuous person, according to the Stoics, will perform a virtuous action, or abstain from action (which in a sense is also an action that involves an assent to an impulse of abstaining), and thus enjoy a benefit, regardless of whether there is food or not. ${ }^{45}$

40 See Stob. 2.99: "The virtuous person, using his experiences with regard to life in what is done by him, does everything well, as he does everything wisely and temperately and according to the other virtues." A similar point is also made in Stob. 2.102.

41 This is a rather simplified picture of Stoic theory of action. Inwood (1985a) offers a thorough account of the complexities that arise in Stoic action theory, which brings together elements from their physics, psychology, and philosophy of language. For the purposes of this article, I am following Chrysippus' rather straight-forward view (itself a point of controversy within the Stoa) that an action takes place only in the $\dot{\gamma} \gamma \varepsilon \mu$ oviкóv itself, with its taking a particular shape (Sen. Ep. 113.23).

42 According to this model of virtue's function, virtue is both a productive and a final good (Stob. 2.71-72; D.L. 7.97; Cic. Fin. 3.55). It is a final good in the sense that it creates and completes happiness by becoming its part, and a productive good, since it produces virtuous actions, which are also part of happiness.

${ }^{43}$ For some of these descriptions of the good, see S.E. M. 11.22; D.L. 7.94; Stob. 2.70.

${ }^{4}$ See D.L. 7.128, where the Stoic claim that virtue is sufficient for happiness is presented: "They (the Stoics) are fond of claiming that virtue is always used, as the followers of Cleanthes say. For virtue cannot be lost, and the wise person always uses his soul, which is perfect."

45 See Alexander of Aphrodisias' complaint that for the Stoics the virtuous person is acting (and, thus, exercising her virtue) even when asleep (de An. 162.1). 
The conclusion from the Stoics' association of action with the use of one's impressions and thoughts, rather than with the acquisition and use of any of the indifferents, or even with the performance of any physical movement, is the Stoics' insistence that the virtuous person will always be able to act, as long as she can think, even when restrained from any physical movement (by being imprisoned and chained to a wall, for example). Consequently, the virtuous person, according to the Stoics, is always able to enjoy the benefit of her actions, even in cases of extreme restriction, although such a life of limited activity is something that she would normally try to avoid. ${ }^{46}$

${ }^{46}$ Versions of this essay have been presented at George Washington University, Marquette University, Portland State University, and Oxford University, as well as at the Joint Sessions and WCPA Conferences at the University of Aberdeen and University of Alberta, respectively. I am grateful for the many useful comments I received during these presentations. I owe many thanks to John Cooper and Hendrik Lorenz, for their guidance and suggestions in the early stages of working on the topic, and the philosophy faculty at the University of Manitoba for their useful discussions while completing it. 


\section{BIBLIOGRAPHY}

Arnim, H. v. (ed.), 1903-1905, Stoicorum Veterum Fragmenta, 3 vols., Leipzig.

Alesse, F., 2000, La Stoa e la Tradizione Socratica, Napoli.

AnNAS, J., 1993, “Virtue as the Use of Other Goods", Apeiron, 26, pp. 53-66.

AnNAS, J., 1999, Platonic Ethics, Old and New, Ithaca.

BARney, R., 2003, “A Puzzle in Stoic Ethics”, Oxford Studies in Ancient Philosophy 24, pp. 303-340.

Bobonich, C., 2002, Plato's Utopia Recast, Oxford.

Brennan, T., 2005, The Stoic Life: Emotions, Duties, and Fate, Oxford.

Brickhouse T., SMith, N., 1994, Plato's Socrates, Oxford.

Burnyeat, M., 2003, “Apology 30b2-4: Socrates, Money, and the Grammar of Gignesthai”, Journal of Hellenic Studies 123, pp. 1-25.

Chance, T. H., 1992, Plato's Euthydemus: Analysis of What Is and Is Not Philosophy, Berkeley.

Cooper, J. M., 1999, “Greek Philosophers on Euthanasia and Suicide”, in: J. M. Cooper, Reason and Emotion, Princeton, pp. 515-541.

Dentsoras, D., 2008, “Seneca and the Old Stoics On Natural Law and Suicide", Maritain Studies/Etudes Maritainiennes 24 , pp. 35-56.

Dillon, J. (trans., comm.), 1993, Alcinous. The Handbook of Platonism, Oxford.

Dimas, P., 2002, "Happiness in the Euthydemus", Phronesis 47, pp. 1-27.

ErLer, M., 2017, Kommentar, in: Platon, Werke, Bd. VI 1: Euthydemos, Göttingen.

Frede, M., 1999, “On the Stoic Conception of the Good”, in: K. Ierodiakonou (ed.), Topics in Stoic Philosophy, Oxford, pp. 71-94.

INwooD, B., 1985, “Goal and Target in Stoicism”, The Journal of Philosophy 10, pp. 547-556.

INwood, B., 1985a, Ethics and Human Action in Early Stoicism, Oxford.

IRwIN, T., 1995, Plato's Ethics, Oxford.

IRwIN, T., 1998, “Socratic Paradox and Stoic Theory”, in: S. Everson (ed.), Ethics, Cambridge, pp. 151-192.

JoNES, R. E., 2013, “Wisdom and Happiness in Euthydemus 278-282”, Philosophers' Imprint 13, pp. 1-21.

Kent Sprague, R. (trans.), 1965, Plato. Euthydemus, Indianapolis.

Long, A. A., 1967., "Carneades and the Stoic telos”, Phronesis 18, pp. 59-90.

Long, A. A., 1988., "Socrates in Hellenistic Philosophy”, The Classical Quarterly 38, pp. 150-171.

Long A. A., Sedley, D. N., 1987, The Hellenistic Philosophers, vol. 1, Cambridge.

PARry, R. D., 2003, “The Craft of Ruling in Plato’s Euthydemus and Republic”, Phronesis 48, pp. 1-28.

Reshotкo, N., 2006, Socratic Virtue: Making the Best of the Neither-Good-Nor-Bad, Cambridge.

RIDER, B., 2012, "Socrates' Philosophical Protreptic in Euthydemus 278c-282d", Archiv für Geschichte der Philosophie 94, pp. 208-228.

Schofield, M., 2003, "Stoic Ethics”, in: B. Inwood (ed.), The Cambridge Companion to the Stoics, Cambridge, pp. 233-256.

Sharples, R. W., 2000, “The Sufficiency of Virtue for Happiness: Not so Easily Overturned?”, Proceeding of the Cambridge Philological Society 46, pp. 121-139.

Sharples, R. W. (transl.), 2004, Alexander of Aphrodisias. Supplement to On the Soul, Ithaca.

STriker, G., 1986, “Antipater, or the Art of Living”, in: M. Schofield, G. Striker (eds.), The Norms of Nature: Studies in Hellenistic Ethics, Cambridge, pp. 185-204. 
STrIKer, G., 1996, "Plato's Socrates and the Stoics", in: G. Striker, Essays on Hellenistic Epistemology and Ethics, Cambridge, pp. 316-324.

VLASTos, G., 1991, Socrates, Ironist and Moral Philosopher, Ithaca.

DIMITRIOS DENTSORAS

/ University of Manitoba, Canada /

dimitrios.dentsoras@umanitoba.ca
KEY WOR DS

\section{Virtue and Proper Use in Plato's Euthydemus and Stoicism}

The essay examines the description of virtue as a craft that governs the proper use of possessions in Plato's Euthydemus and Stoicism. In the first part, I discuss Socrates' parallel between wisdom and the crafts in the Euthydemus, and the resulting argument concerning the value of external and bodily possessions. I then offer some objections, showing how Socrates' craft analogy allows one to think of possessions as (qualifiedly) good and ultimately fails to offer a defense of virtue's sufficiency for happiness. In the second part, I examine the Stoics' craft analogy and note a number of differences from Socrates' account in the Euthydemus. These include the Stoic claim that external advantages never make any contribution to happiness, even when properly used, and the claim that, unlike other crafts, wisdom does not require any external possessions in order to be exercised and yield benefit and happiness. I then place these differences against the backdrop of the debate regarding virtue's sufficiency for happiness and argue that the Stoic craft model of virtue fares better than its Socratic antecedent.

Stoicism, Euthydemus, virtue, craft analogy, eudaimonism 